\title{
Effect of Wood Biomass Ash Storage on the Properties of Cement Composites
}

\author{
Ivana Carević $^{1, *}$, Nina Štirmer ${ }^{1} \mathbb{D}$, Marijana Serdar $^{1}\left(\mathbb{D}\right.$ and Neven Ukrainczyk ${ }^{2} \mathbb{D}$ \\ 1 Department of Materials, Faculty of Civil Engineering, University of Zagreb, Fra Andrije Kačića Miošića 26, \\ 10000 Zagreb, Croatia; nina.stirmer@grad.unizg.hr (N.Š.); marijana.serdar@grad.unizg.hr (M.S.) \\ 2 Institute of Construction and Building Materials, Technical University of Darmstadt, \\ Franziska-Braun-Straße 3, 64287 Darmstadt, Germany; ukrainczyk@wib.tu-darmstadt.de \\ * Correspondence: ivana.carevic@grad.unizg.hr; Tel.: +385-1-4639-422
}

Citation: Carević, I.; Štirmer, N.; Serdar, M.; Ukrainczyk, N. Effect of Wood Biomass Ash Storage on the Properties of Cement Composites. Materials 2021, 14, 1632. https:// doi.org/10.3390/ma14071632

Academic Editors: Vilma Ducman, Adriana Bernardi and Ana Mladenovic

Received: 17 February 2021

Accepted: 22 March 2021

Published: 26 March 2021

Publisher's Note: MDPI stays neutral with regard to jurisdictional claims in published maps and institutional affiliations.

Copyright: (C) 2021 by the authors. Licensee MDPI, Basel, Switzerland. This article is an open access article distributed under the terms and conditions of the Creative Commons Attribution (CC BY) license (https:/ / creativecommons.org/licenses/by/ $4.0 /)$.

\begin{abstract}
Since ash from wood biomass mostly ends up in landfills, recent research has focused on finding its economic and environmental added value as a potential new raw material in the construction industry. However, for wood ash to be used on an industrial scale in construction, a strategy for its proper storage must be defined. Proper storage of WBA is important to ensure quality control for applications in cementitious composites. This work investigated the aging of wood biomass ash (WBA) collected from five different power plants in Croatia and its influence on the performance of cementitious composites. WBA and cement pastes were investigated at different aging times (up to one year) using thermogravimetric analysis (TGA), powder X-ray diffraction (XRD), isothermal calorimetry and initial and final setting times. The results showed that storage of WBA in closed and open containers resulted in carbonation and hydration of mainly free lime and periclase, respectively, which affected the reactivity and setting times of WBA cement pastes.
\end{abstract}

Keywords: wood biomass ash; cement-based materials; cement partial replacement; aging; hydration; carbonation

\section{Introduction}

The use of wood biomass as one of the renewable sources of energy has increased significantly in recent years [1,2]. This results in a growing amounts of wood biomass ash (WBA) waste being generated in such energy power plants. Statistical European data show increased use of solid biofuels [3], with solid biomass having one of the largest increases [4]. The authors estimated that approximately $15.5 \mathrm{t} \times 10^{6} \mathrm{t}$ of WBA [5] was produced in 2015, while the projection of WBA produced is expected to triple by 2020, implying the need for a future strategy for WBA management. WBA is mostly disposed [5,6], so recent research has focused on finding added economic and environmental values for WBA, e.g., as a potential new raw material in the construction industry [7-11]. The recovery and reuse of WBA poses logistical challenges to owners and managers of wood biomass power plants, as well as companies that collect WBA from power plants, as shown in Figure 1. In particular, the storage pre-treatment and transportation from the power plant to the user of this by-product seems to be a critical point. Proper storage of WBA should not only include prevention of pollution and healthy concerns but may also significantly affect the quality of the WBA. Therefore, detailed characterization of WBA is the first and most important step to decide about the appropriate treatment and use of WBA [12,13]. Namely, for the application of WBA as a mineral additive in cementitious composites, there is a need to understand the aging of WBA in terms of chemical and mineral changes induced during the various storage conditions. 


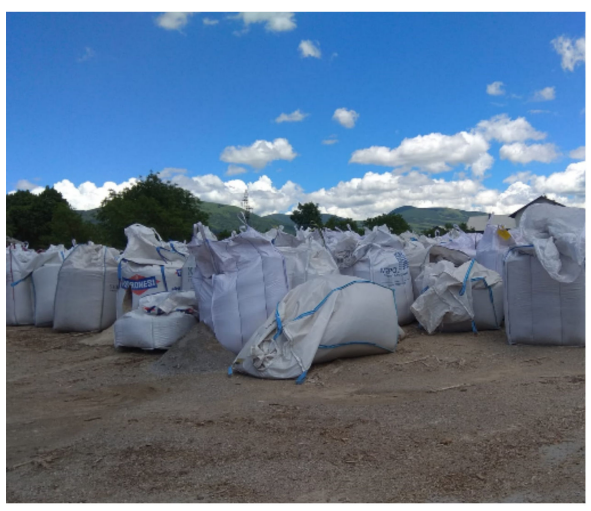

(a)

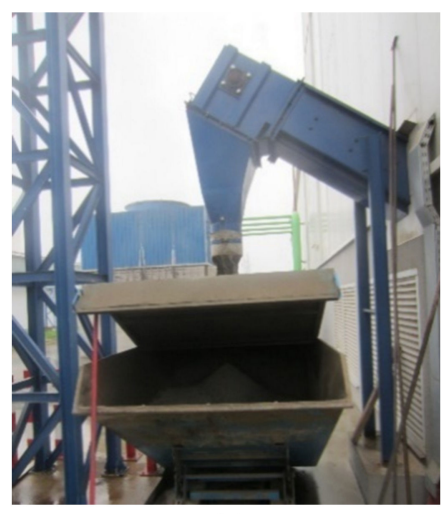

(b)

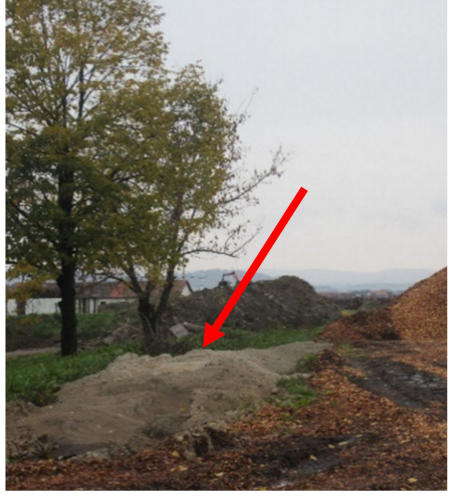

(c)

Figure 1. Different approaches to wood biomass ash (WBA) storage: (a) in plastic bags; (b) in the container; (c) landfilling.

WBA has hydraulic and latent hydraulic (pozzolanic) properties and therefore has shown great potential to partly replace conventional cements and thus improve environmental impact of construction materials. Cementitious raw materials in general and thus also WBAs are highly hydrophilic, i.e., they readily absorb water vapor, which is commonly referred to as pre-hydration [14]. Pre-hydration leads to partial hydration of the surface of the cementitious grains. This phenomenon can occur during the production process, e.g., already in a clinker mill, or later during storage [15]. Based on the laboratory tests conducted by [16], cement loses its fineness during prolonged storage. When the cement absorbs moisture, the hydration process begins and forms chemical hydration bonds between the aggregated cement particles, also called "lumps". Initially, the formed lumps may break and become fine, but when the storage time is extended, the lumps cannot break and therefore become rigid. As cement ages, its reactivity decreases, resulting in decreased compressive strength, prolonged setting time, and increased water demand [17-19]. It has been found that cement aging leads to the formation of early reaction products, mainly ettringite and syngenite, on the surfaces of clinker grains [20], and carbonates. Therefore, the optimal shelf life of Portland cement is not more than 3 months. If it is stored for more than 3 months, the properties (e.g., strength) of the cement should be tested to determine whether aging had significantly affected its properties. However, if properly stored under dry conditions and sufficiently low relative humidity $\left(20^{\circ} \mathrm{C}\right.$ and $<35 \%$ r.h.), cement can be expected not to change its properties for several years [21].

Like in use of cement, also when considering the use of wood biomass ash (WBA) as a supplementary cementitious material in the concrete industry, it is important to understand the aging, i.e., the quality change during storage of WBA. There are studies on the process of natural [22-25] and accelerated aging of materials [26], which are also relevant in the case of WBA $[27,28]$. It had already been established that pre-hydration and carbonation can have a positive effect on the application of WBA in agriculture and forestry by lowering its $\mathrm{pH}$ value [28]. In addition, pre-hydration may have a positive effect on reducing dust generation during transport and application of WBA, as well as reducing Ca leaching $[26,27,29,30]$. WBA has a high content of $\mathrm{CaO}$ (and $\mathrm{MgO}$ ), which can initially be in the form of free lime (and periclase) and can spontaneously hydrate and rapidly carbonate under humid conditions [31]. In particular, the amount of free $\mathrm{CaO}$ against carbonate products depends not only on the type of a wood biomass being burned but also on the firing, storage and transport conditions of the WBA. Any change in the chemical/mineralogical composition of WBA during storage could have an impact on the properties of composites made with WBA. For this reason, the storage of WBA becomes a challenge: it must be ensured that WBA does not lose its reactivity during storage.

The main objective of this work was to evaluate the influence of WBA aging on the performance of cement composites, as a step towards defining an optimal strategy for WBA storage when used as a raw material in the concrete industry. The research focussed on 
five different types of WBA samples collected from power plants using grate combustion system (which are not water-cooled). WBAs collected from such plants show self-cementing properties over time [31-34] and therefore more knowledge about their use and storage is required.

\section{Materials and Methods}

\subsection{Materials}

Wood biomass fly ashes from five different power plants in Croatia were used in this study. The characterization of the used WBAs and cement (chemical composition, particle size distribution, particle morphology) has already been described in detail by [7]. A summary of the chemical and physical properties of WBAs and cement is presented in Table 1 and Figure 2. The input parameters of the power plants (average combustion temperatures, technology of combustion, and biomass used in the power plants) are given in Table 1 and are discussed in detail in [35].

Table 1. Chemical and physical properties of the wood biomass ash (WBA) samples and cement.

\begin{tabular}{|c|c|c|c|c|c|c|}
\hline Parametar & CEM I & WBA1 & WBA2 & WBA3 & WBA4 & WBA5 \\
\hline $\mathrm{P}_{2} \mathrm{O}_{5}($ mass $\%)$ & 0.22 & 2.60 & 1.84 & 1.82 & 1.35 & 4.03 \\
\hline $\mathrm{CaO}$ (mass \%) & 59.80 & 48.70 & 51.90 & 46.75 & 16.25 & 47.35 \\
\hline $\mathrm{MgO}(\operatorname{mass} \%)$ & 2.01 & 4.79 & 3.75 & 8.26 & 4.30 & 4.71 \\
\hline $\mathrm{TiO}_{2}$ (mass \%) & 0.23 & 0.15 & 0.15 & 0.34 & 1.17 & 0.25 \\
\hline $\mathrm{SO}_{3}$ (mass \%) & 3.33 & 4.77 & 3.58 & 2.73 & 0.60 & 3.95 \\
\hline $\mathrm{Na}_{2} \mathrm{O}_{\mathrm{eq}}($ mass $\%)$ & 1.67 & 10.90 & 6.60 & 4.63 & 4.59 & 4.72 \\
\hline Pozzolanic oxides $\left(\mathrm{SiO}_{2}+\mathrm{Al}_{2} \mathrm{O}_{3}+\mathrm{Fe}_{2} \mathrm{O}_{3}\right)$ & 29.97 & 12.29 & 13.03 & 28.81 & 54.68 & 19.70 \\
\hline Free $\mathrm{CaO}$ (mass \%) & 2.50 & 8.60 & 13.50 & 7.30 & 0.50 & 8.80 \\
\hline Free $\mathrm{MgO}$ (mass \%) & 0.75 & 4.20 & 3.80 & 3.30 & 0.50 & 4.50 \\
\hline $\mathrm{Cl}^{-}(\operatorname{mass} \%)$ & 0.04 & 0.06 & $<0.003$ & 0.04 & 0.04 & $<0.003$ \\
\hline LOI $\left(950{ }^{\circ} \mathrm{C}\right)$ & 3.6 & 13.4 & 13.8 & 3.8 & 8.3 & 12.7 \\
\hline $\mathrm{pH}$ & 12.86 & 13.37 & 13.25 & 13.15 & 12.97 & 13.22 \\
\hline Density $\left(\mathrm{g} / \mathrm{cm}^{3}\right)$ & 3.1 & 2.59 & 2.59 & 2.59 & 2.63 & 2.33 \\
\hline Bulk density $\left(\mathrm{kg} / \mathrm{m}^{3}\right)$ & $\mathrm{n} / \mathrm{a}$ & 0.38 & 0.38 & 0.91 & 0.61 & 0.55 \\
\hline $\mathrm{d}_{50}(\mu \mathrm{m})$ & 9.6 & 18.2 & 43.3 & 71.9 & 120.7 & 17.8 \\
\hline Technology used & - & $\begin{array}{l}\text { Pulverized fuel } \\
\text { combustor }\end{array}$ & $\begin{array}{l}\text { Pulverized fuel } \\
\text { combustor }\end{array}$ & $\begin{array}{c}\text { Grate } \\
\text { combustor }\end{array}$ & $\begin{array}{c}\text { Grate } \\
\text { combustor }\end{array}$ & $\begin{array}{c}\text { Bubbling } \\
\text { fluidized bed }\end{array}$ \\
\hline Type of wood used & - & $\begin{array}{c}\text { Beech, oak, } \\
\text { hornbeam, poplar, } \\
\text { cherry }\end{array}$ & $\begin{array}{l}\text { Beech, oak, } \\
\text { hornbeam }\end{array}$ & $\begin{array}{l}\text { Beech, oak, } \\
\text { abies, picea }\end{array}$ & $\begin{array}{l}\text { Beech, oak, } \\
\text { hornbeam }\end{array}$ & $\begin{array}{l}\text { Beech, oak, } \\
\text { hornbeam, } \\
\text { poplar }\end{array}$ \\
\hline Average temperature, ${ }^{\circ} \mathrm{C}$ & - & $700-750$ & $700-750$ & $700-950$ & 800 & 850 \\
\hline
\end{tabular}

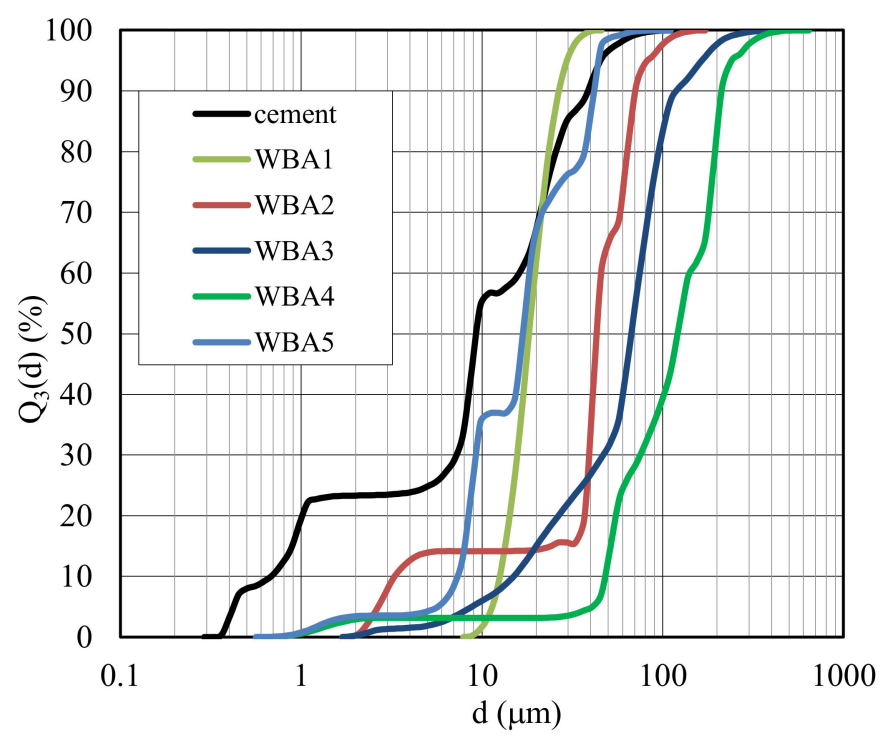

Figure 2. Particle size distribution $[7,36]$. 
WBAs were collected from October to January and periodically tested by thermogravimetric measurements, while chemical and physical properties of WBAs were done from January to April, 2018. During the WBA collection, an attempt was made to take "fresh" WBAs that had just come out of the furnace or chimney ("fresh" top WBA from inside the container (WBA1, WBA2, WBA4, WBA5) or plastic bag (WBA3) at the power plant). Cement paste was prepared in May/June 2018 and in the same period after one year of WBA aging. Powder X-ray diffraction (XRD) and calorimetric measurements, as well as the properties of the pastes in the fresh state, were measured on WBAs stored in plastic bags kept in closed plastic containers under laboratory conditions $\left(20{ }^{\circ} \mathrm{C}\right.$ and $50 \%$ $\mathrm{RH})$. About $5 \mathrm{~kg}$ of WBA were collected at power plant, of which $100 \mathrm{~g}$ were used for TG and XRD measurements at different storage conditions (one representative sample per different WBA was used for test). The other part of the collected WBA was used for paste preparation, using fresh WBA (in initial state) and after one year.

Two storage conditions were simulated (one sample per condition): (i) in closed containers to simulate storage in concrete plants, and (ii) under open laboratory conditions to simulate outdoor storage in power plants. TG analysis of WBAs and cement were performed at different sample ages: Samples were tested immediately after collecting of WBA (initial condition) and after 7 and 28 days and 1 year of storage in closed plastic bags-simulating storage in closed containers. Part of the samples were stored in open containers exposed to the air and humidity conditions of the laboratory $\left(20{ }^{\circ} \mathrm{C}\right.$ and $50 \%$ $\mathrm{RH}$ )-simulating open landfilling. These samples were tested after 3 and 6 months of WBA age of the samples.

\subsection{Thermogravimetric Measurement}

Thermogravimetric (TG) measurements of WBA and cement stability were performed on a LECO TGA 701 (LECO Corporation, MI, USA) using a ceramic vessel filled with approximately $1 \mathrm{~g}$ of powder sample. For all samples, the temperature interval of the measurement ranged from 35 to $950{ }^{\circ} \mathrm{C}$ at a heating rate of $20{ }^{\circ} \mathrm{C} / \mathrm{min}$. The sample chamber was filled with inert gas (nitrogen, flow: $30 \mathrm{~mL} / \mathrm{min}$ ) to prevent oxidation during the measurement. Before measurement, the samples were dried for at $35{ }^{\circ} \mathrm{C}$. for $15 \mathrm{~min}$ to lose moisture. Calcite $\left(\mathrm{CaCO}_{3}\right)$ values were determined from the TG measurement. Calcite decomposes to $\mathrm{CaO}$ and $\mathrm{CO}_{2}$ at temperatures above $600{ }^{\circ} \mathrm{C}$. Mass loss $\left(W L_{\mathrm{CaCO}}\right)$ can be used to determine calcite using the molecular weight of $\mathrm{CaCO}_{3}\left(m_{\mathrm{CaCO} 3}=100 \mathrm{~g} / \mathrm{mol}\right)$ and $\mathrm{CO}_{2}(44 \mathrm{~g} / \mathrm{mol})$ as follows:

$$
\mathrm{CaCO}_{3}=W L_{\mathrm{CaCO} 3} \times m_{\mathrm{CaCO} 3} / m_{\mathrm{CO} 2}
$$

The mass loss of the sample as delivered from 35 to $950{ }^{\circ} \mathrm{C}$ can be defined as a baseline from which incremental prehydration of the sample powder can be defined as additional mass loss in the same temperature range of that powder at a later time. Therefore, the prehydration index (PI) can be calculated as follows [37]:

$$
\mathrm{PI}=\left[\left(\frac{\Delta m}{m_{i}}\right)-\left(\frac{\Delta m_{0}}{m_{0}}\right)\right] \times 100
$$

where:

- $\Delta m$-mass loss between 35 to $950{ }^{\circ} \mathrm{C}$, or mass loss between 35 to $600{ }^{\circ} \mathrm{C}$;

- $\Delta m_{0}$-mass loss between 35 to $950{ }^{\circ} \mathrm{C}$ or mass loss between 35 to $600{ }^{\circ} \mathrm{C}$ for sample in the initial state;

- $\quad m_{\mathrm{i}}$-mass of sample at $950{ }^{\circ} \mathrm{C}$ or mass at $600{ }^{\circ} \mathrm{C}$;

- $\quad m_{0}$-mass of sample at $950{ }^{\circ} \mathrm{C}$ or mass at $600{ }^{\circ} \mathrm{C}$ in initial state.

$\mathrm{PI}_{950}$ includes carbonation from a direct effect of ageing and a secondary effect of reaction with water. Within $\mathrm{PI}$, carbonation includes the formation of $\mathrm{CaCO}_{3}$ by the direct carbonation of free lime $(\mathrm{CaO})$ in the sample, the carbonation of $\mathrm{Ca}(\mathrm{OH})_{2}$ formed by the hydration of $\mathrm{CaO}$, and the reaction of free lime with water vapour water in the air, forming 
silica and portlandite phases [37]. To separate the influence of hydration and carbonation, $\mathrm{PI}_{600}$ was also investigated as mass loss between 35 and $600{ }^{\circ} \mathrm{C}$ compared to the initial state.

\subsection{XRD Analysis}

Diffractograms of the samples were obtained by powder X-ray diffraction (XRD) using a Philips MPD 1880 diffractometer (Philips, Almelo, The Netherlands). Powdered samples were scanned between $5^{\circ}$ and $70^{\circ}$ with a step size of $0.02^{\circ}$ using $\mathrm{CuK} \alpha_{1,2}$ radiation. Quantification of free $\mathrm{CaO}$ and free $\mathrm{MgO}$ minerals was analyzed using a Bruker desktop diffractometer (Bruker, Ettlingen, Germany) with a fast linear LYNXEYE detector (5 degrees opening). A detailed description of the method can be found in [7]: The quantitative analysis was based on the adiabatic principle with auto flushing [38] where the relationship between the peak area of the characteristic X-ray reflection Ii is directly proportional to the weight fraction of the component by the factor ki, which contains the mass absorption coefficient of the total sample. The ki values were determined by mixing pure phases $(\mathrm{CaO}$ and $\mathrm{MgO})$ with corundum $\left(\mathrm{Al}_{2} \mathrm{O}_{3}\right)$ in a 50:50 weigh ratio. Each sample prepared for QXRD ( $1 \mathrm{~g})$ was mixed with a fixed amount of corundum $(0.1 \mathrm{~g})$ and then ground and homogenized in an agate mortar under acetone. Appropriate corrections for peak overlap were meticulously applied by inference to the (measured) intensities of the pattern due to the pure phases.

\subsection{Isothermal Calorimetry}

Heat release data of cementitious pastes were obtained by isothermal calorimetry, where the water to cementitious materials ratio was 0.5 and $15 \%$ of OPC was replaced by wood biomass ash. About $20 \mathrm{~g}$ of the paste samples were mixed for $3 \mathrm{~min}$, and $6 \mathrm{~g}$ of the sample was placed in a sealed ampoule and lowered into the calorimeter (TA Instruments, New Castle, DE, USA), which had been conditioned to $20 \pm 0.05^{\circ} \mathrm{C}$. The WBA used in this test was over one year old.

\subsection{Mix Design}

CEM I $42.5 \mathrm{R}$ cement and water at a temperature of $20 \pm 2{ }^{\circ} \mathrm{C}$ were used to prepare paste samples. The reference mix (P0) was prepared using $500 \mathrm{~g}$ of CEM I $42.5 \mathrm{R}$ and $125 \mathrm{~g}$ of water according to EN 196-3 [39], while 15\% WBA was used as cement replacement for the preparation of the other pastes. Based on previous research $[36,40]$ and due to workability issues, $15 \%$ of WBA was used as cement replacement in this experiment. The amount of water in the paste samples was varied to obtain standard consistency. The standard consistency of the paste was determined using the Vicat apparatus according to the standard EN 196-3 [39] where the Vicat must penetrate to a point $6 \pm 2 \mathrm{~mm}$ from the bottom of the Vicat mould. In addition to standard consistency, temperature and setting time were also tested.

\section{Results and Discussion}

\subsection{Aging of WBA Samples Stored in Closed Containers}

To investigate shelf life and changes in properties of WBA in closed environment, the changes in mineralogical composition were monitored by TG and XRD for one month and after one year. Figure 3 shows the TGA of WBA powders and cement measured immediately after collecting WBA powders from the power plants and after one year of storage in the closed plastic containers. From the TGA diagram, usually three main peaks can be distinguished for prehydrated cement [37,41,42]: The first peak between 50 and $250{ }^{\circ} \mathrm{C}$ is attributed to the decomposition of hydration products $(\mathrm{C}-\mathrm{S}-\mathrm{H}$, ettringite and monosulphate); the second peak refers to the decomposition of portlandite between 400 and $600{ }^{\circ} \mathrm{C}$ to $\mathrm{CaO}$ and $\mathrm{H}_{2} \mathrm{O}$, and the third peak at about $700{ }^{\circ} \mathrm{C}$ is attributed to the decomposition of calcium carbonate to $\mathrm{CaO}$ and $\mathrm{CO}_{2}$. All WBA samples showed a distinctive third peak in the initial state (immediately after collection) or a large share of $\mathrm{CaCO}_{3}$ immediately after collection (Figure $3 a$ ). The $\mathrm{CaCO}_{3}$ content of the WBA samples 
immediately after collection is in the following order from higher to lower values: WBA2 $(32.74 \%)>$ WBA1 $(28.72 \%)>$ WBA5 $(27.26 \%)>$ WBA3 $(8.04 \%)>$ WBA4 $(6.99 \%)$. In this research, WBA samples with higher $\mathrm{CaCO}_{3}$ values after collection were mainly found to be primarily samples that also had finer particles and a higher proportion of free lime. The authors stated that the temperature in the grate combustion can reach up to $1000-1200^{\circ} \mathrm{C}$, in fluidized bed combustion plants combustion temperatures are lower (less than $900^{\circ} \mathrm{C}$ ), while in the pulverized fuel combustor plants temperatures can reach up to $1600{ }^{\circ} \mathrm{C}$ compared to other combustion systems. The mineralogy of WBA changes with the temperature of furnace: At lower temperatures (around $600^{\circ} \mathrm{C}$ ), carbonates are the main phases, while at higher temperatures (up to $1300^{\circ} \mathrm{C}$ ) free $\mathrm{MgO}$ and $\mathrm{CaO}$ are expected to be main phases [43]. According to Table 1, all temperatures in the power plants where WBA was collected were lower $\left(700-950^{\circ} \mathrm{C}\right)$, but these temperatures are average values and higher temperatures in the furnace could be expected as well. Samples WBA5 from power plants with bubbling fluidized bed and WBA samples WBA1 and WBA2 from power plants with pulverized fuel combustors showed higher values of $\mathrm{CaCO}_{3}$ content compared to samples collected from power plants with grate combustion technology (WBA3 and WBA4).

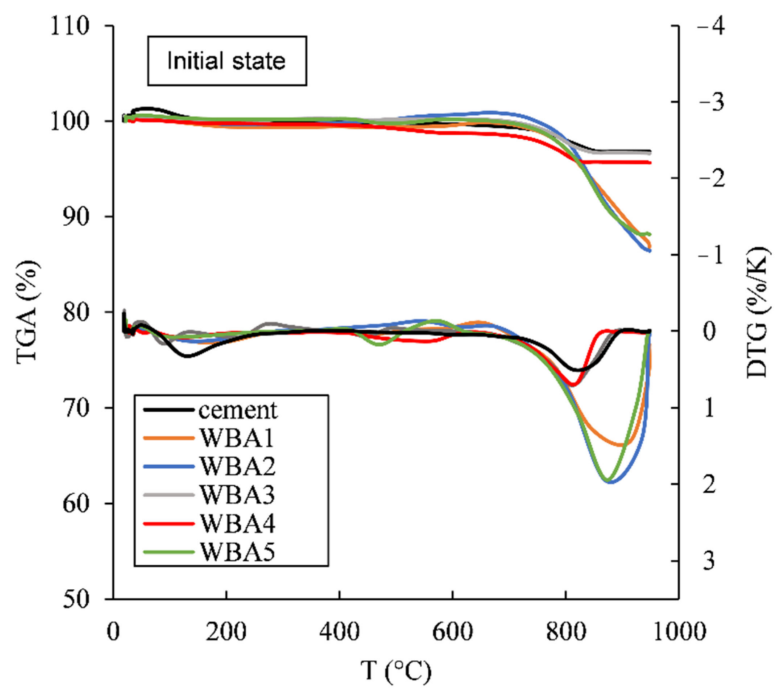

(a)

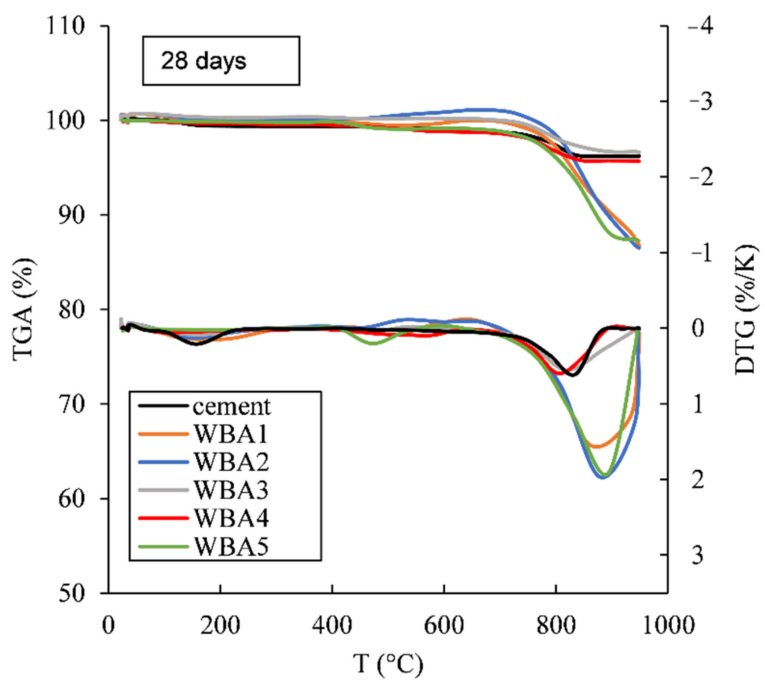

(b)

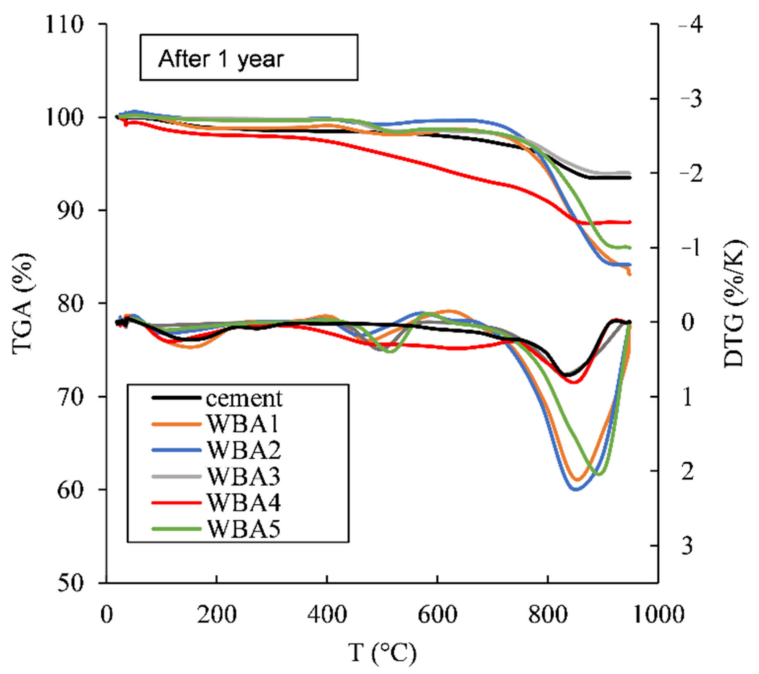

(c)

Figure 3. Thermogravimetric (TG) and differential thermogravimetry (DTG) curves of cement and wood biomass ash (WBA) samples for: (a) initial state; (b) 28 days, and (c) after 1 year (the data are available in Supplementary Materials). 
There were no significant changes in the TG and DTG curves after 28 days (Figure 3b), but after one year of aging in the closed containers, it is evident from the TGA (Figure 3c) that there is an increase in the amount of hydration products (first and second peak) and carbonation products (third peak). It is necessary to additionally highlight the results for the WBA4 sample after one year: There is an obvious mass loss over a wide temperature range, suggesting calcium silicate hydrate [21]. This could indicate that WBA4 sampling or storage conditions might have affected the moisture condition, although the seal has been checked in several time periods. Additionally, TG measurements were repeated for this sample, but the results were the same. In any case, apart from carbonation, the aging of WBA sample indicated hydraulic and/or pozzolanic reactivity. The chemical composition of WBA4 differs from other WBAs where higher pozzolanic oxides can be seen which could affect the aging process, but this needs to be confirmed by further research. Changes in carbonate content over time for each tested sample stored in closed containers, determined according to Equation (1), are shown in Figure 4. A large amount of carbonate phase is visible in all WBA samples, especially in WBA 1 , WBA 2, and WBA5. It must be emphasised that when the carbonate content is high, as in these WBA samples, it is necessary to select the correct method for determining content of unburned carbon (UC), especially LOI testing, as one of the main characterization tools for supplementary cementitious materials (SCM) [44-46]. Generally, LOI values of WBA from Table 1 determine WBA as low-quality ash for application as mineral admixture if compared with requirements given by EN 450-1 [47]. Mineral additions with high content of UC can lead to increase water demand due to a high specific surface area [48].

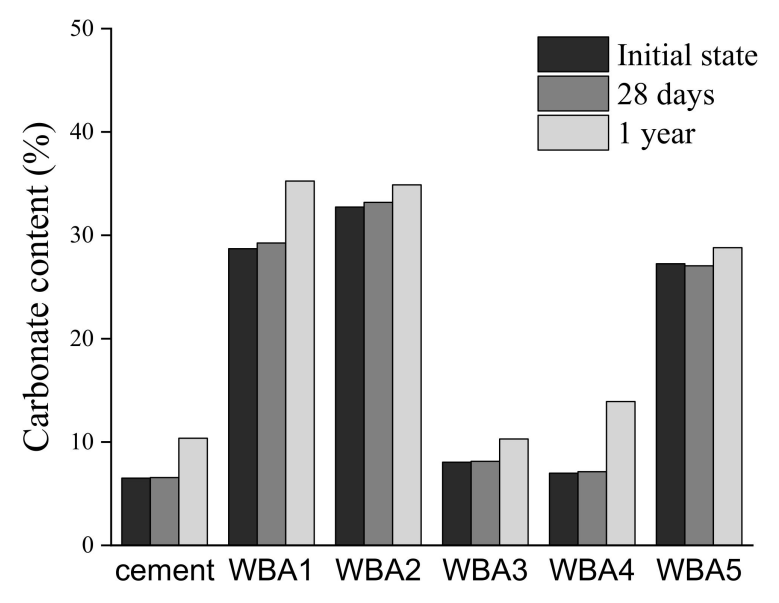

Figure 4. Carbonate content for WBA samples and cement per time according to equation 1.

In order to distinguish the influence of carbonation and hydration of the WBA samples, the pre-hydration index (Equation (2)), i.e., the change in mass loss of the tested sample in time per initial state, i.e., normalized per initial state) was calculated for different temperature ranges and shown in Figure 5. $\mathrm{PI}_{600}$ mainly includes the influence of hydration, while $\mathrm{PI}_{950}$ includes the carbonation and hydration of the WBA samples normalized to the WBA initial state results.

From Figure 5, it can be seen that WBA storage in closed containers for 28 days showed no increasing PI values, or no significant change in TGA results was observed for WBA aging for 28 days. $\mathrm{PI}_{600}$ values after 28 days were from $0.15 \%$ (WBA4) to $0.51 \%$ (WBA5), while for $\mathrm{PI}_{950}$ the values were from 0.21 (WBA4) to $0.85 \%$ (WBA1). However, after one year, there was a slight increase in mass loss between 35 and $600{ }^{\circ} \mathrm{C}$ and a more significant increase in mass loss between 35 and $950{ }^{\circ} \mathrm{C}$, suggesting that carbonation of WBA samples stored in closed containers is more pronounced during aging. Here, sample WBA4 stands out as it shows the largest mass increase of all the samples studied from the time of collection (initial state) until storage in the closed container after one year. For sample WBA4, the values for indices $\mathrm{PI}_{600}$ and $\mathrm{PI}_{950}$ were $3.62 \%$ and $8.39 \%$, respectively. Sample 
WBA3 had the second highest mass increase during aging $\left(\mathrm{PI}_{600}\right.$ and $\mathrm{PI}_{950}$ were $1.54 \%$ and $6.36 \%$, respectively), while sample WBA5 had the lowest mass increase $(0.96 \%$ and $2.25 \%$ ). Both samples with the highest increase in carbonation products (WBA4 and WBA3) were from power plants using grate combustion technology (with higher combustion temperature), implying that aging could have a greater impact on the WBA generated from this technology, as it promotes the complete decomposition of carbonates $\left(\mathrm{CaCO}_{3}\right.$ and dolomite stones) into the free lime (and periclase). The influence of each chemical and physical property of the WBA on the increase in carbonation products was statistically analysed and the only parameter that had a statistically significant influence was particle size (Figure 6). Samples with larger particle sizes exhibited faster carbonation. A similar trend can be seen in the study of [28] where WBA samples with larger particles size from grate combustion showed higher mass increase when stored outdoors compared to other samples. The possible influence of combustion technology on the carbonation process of WBA samples should be further investigated.

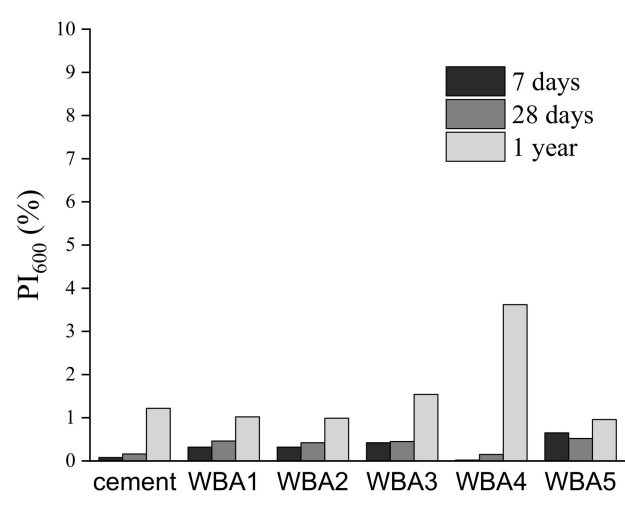

(a)

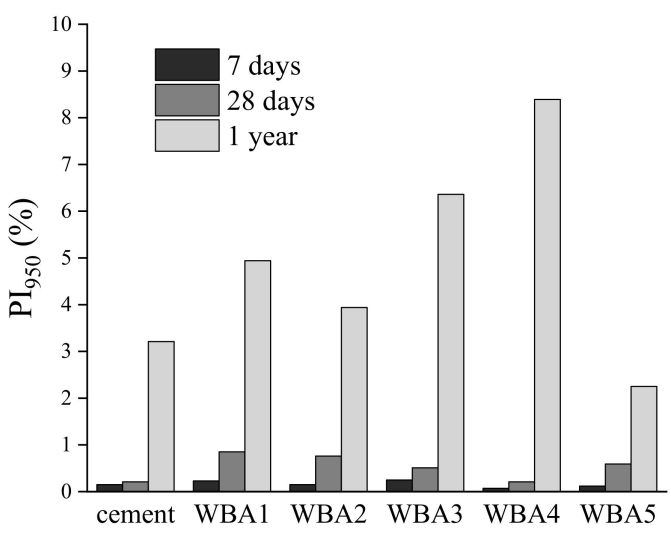

(b)

Figure 5. (a) $\mathrm{PI}_{600}$ value for WBA samples (7 days, 28 days, and 1 year) for temperatures between 35 and $600{ }^{\circ} \mathrm{C} ;(\mathbf{b}) \mathrm{PI}_{950}$ value for WBA samples (7 days, 28 days, and 1 year) for temperatures between 35 and $950{ }^{\circ} \mathrm{C}$.

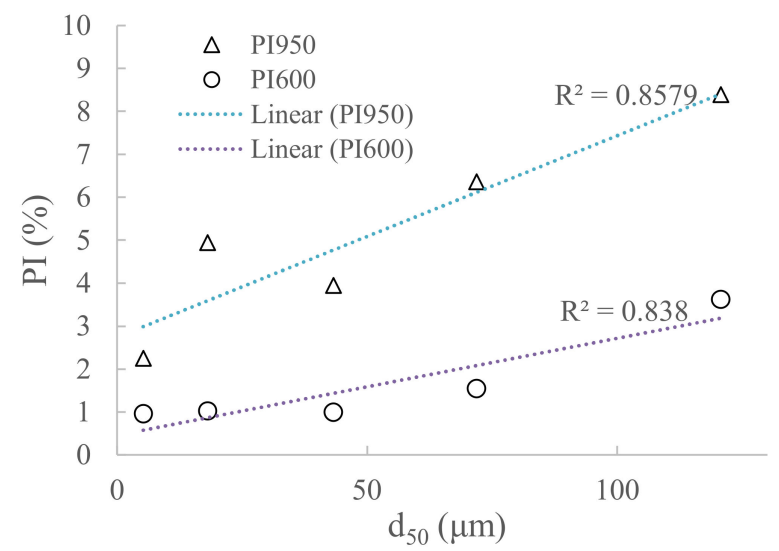

Figure 6. Effect of fineness of WBA samples on pre-hydration index after 1 year $\left(\mathrm{PI}_{950}\right.$ and $\left.\mathrm{PI}_{600}\right)$.

The results of XRD analysis of the tested WBA samples are shown in Figure 7 where the main phases were identified as follows: $\mathrm{Cc}$-calcium carbonate $\left(\mathrm{CaCO}_{3}\right), \mathrm{Q}-$ quartz $\left(\mathrm{Si}_{2} \mathrm{O}\right)$, $\mathrm{C}$ - calcium oxide $(\mathrm{CaO}), \mathrm{M}$ - periclase $(\mathrm{MgO})$, and $\mathrm{P}$ - portlandite $\left(\mathrm{Ca}(\mathrm{OH})_{2}\right)$. Comparing the diffractograms of the initial samples and those after one year of storage in closed containers, a strong decrease in the peaks of calcium oxide (lime) and magnesium oxide (periclase) can be seen. Therefore, some decrease in the amount of free $\mathrm{CaO}$ in closed containers can be expected. Materials with a high amount of free $\mathrm{MgO}$ and free $\mathrm{CaO}$ in concrete increase the risk of volume instability (swelling) during the hydration process, and 
the formation of cracks [49-51]. According to Table 1, the collected WBA have higher free $\mathrm{CaO}$ values compared to cement, but the soundness test results [36] showed that cement paste mixes with $15 \%$ WBA as cement replacement met the requirement of the standard EN 450-1 [47]. Free $\mathrm{CaO}$ is very sensitive to atmospheric moisture and carbon dioxide [52-54], leading to phase changes within the material $[28,55,56]$. The present results suggest when WBA is stored in closed containers, the free lime is stabilised over time, i.e., its reaction with water and $\mathrm{CO}_{2}$ is significantly delayed due to their limited availability by mass transport. This form of stabilization could be positive, as a decrease in free lime leads to a lower risk of volume instability when higher dosages of WBA are used as a cement replacement.
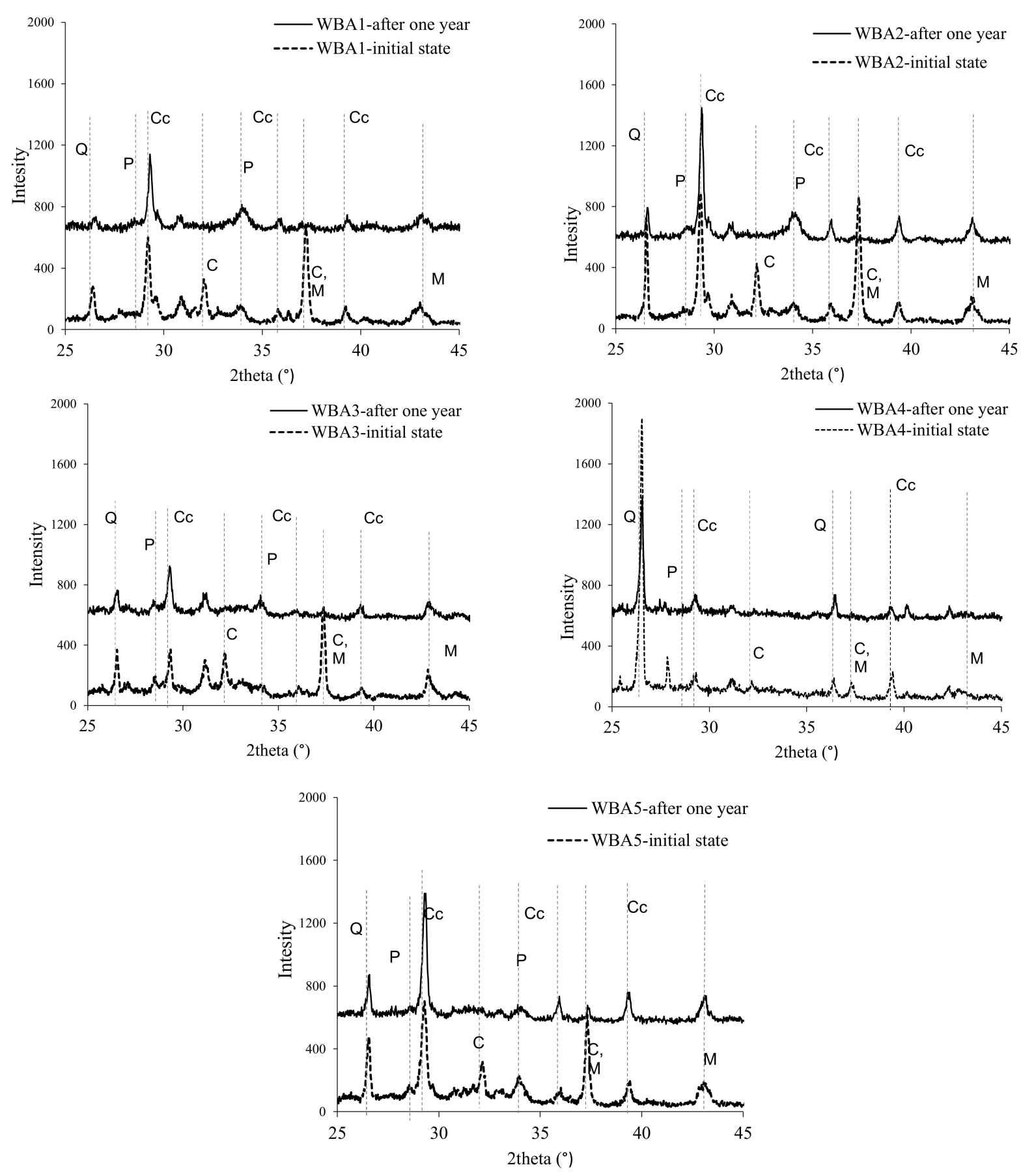

Figure 7. XRD diffractograms of WBA samples after collecting from power plants and after one year of storage in closed containers (the data are available in Supplementary Materials). 
In order to evaluate the effect of aging in closed containers on the properties of cement pastes, setting time, standard consistency as well as cement paste temperature were tested with WBA delivered and with WBA stored in closed container for one year. Figure 8 shows the results of the standard consistency, setting time, and temperature of the pastes with $15 \% \mathrm{WBA}$ as cement replacement $\left(\mathrm{M}-\mathrm{WBA}_{\mathrm{i}}\right)$. WBA was used after collection from power plants (initial state) and after one year of aging, stored in closed containers (after one year). All results were normalized with respect to the reference mix.

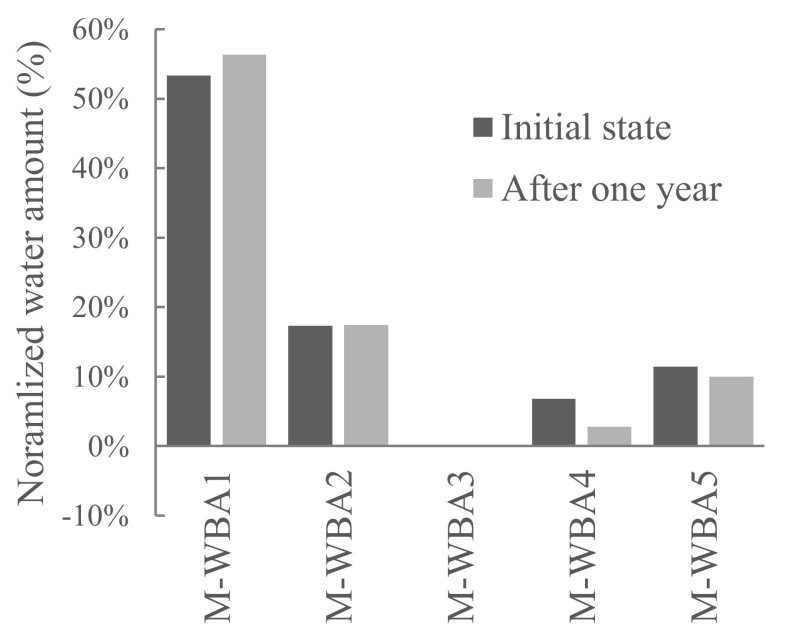

(a)

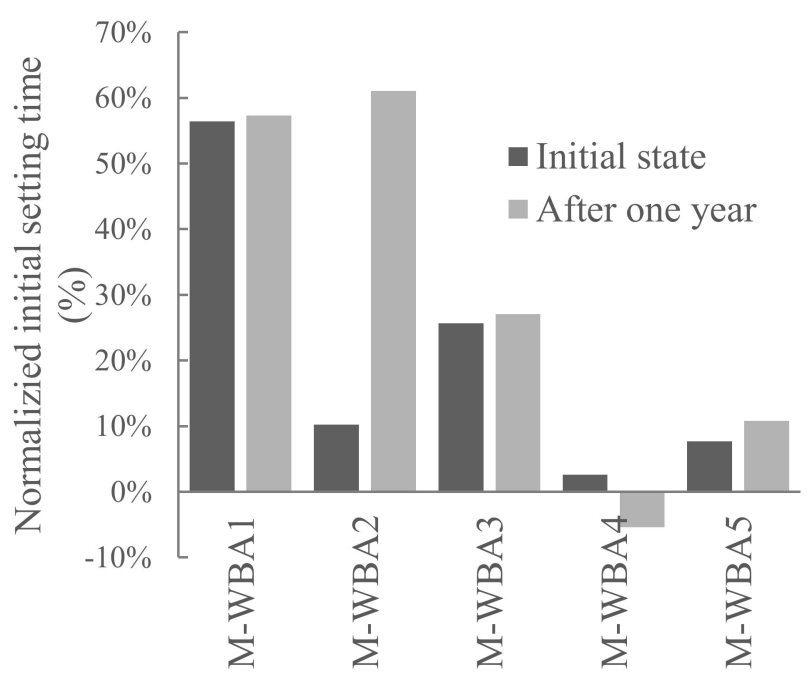

(c)

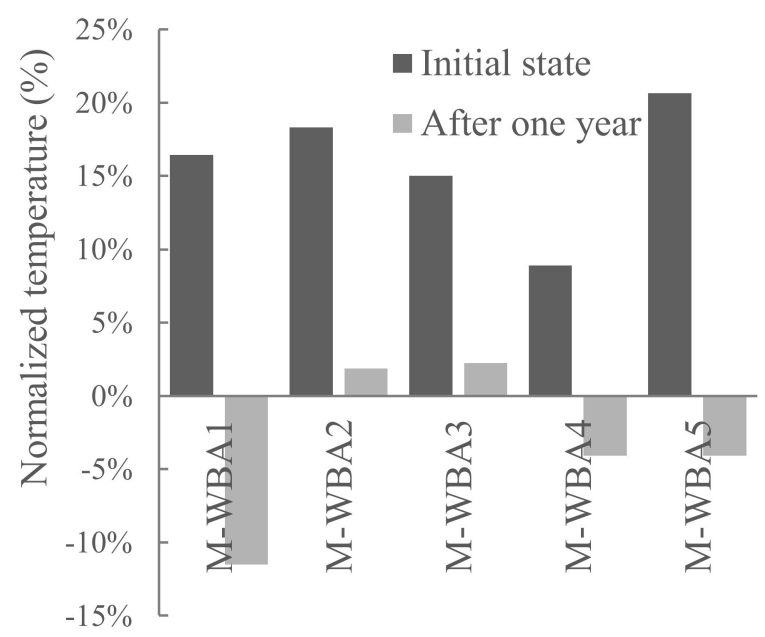

(b)

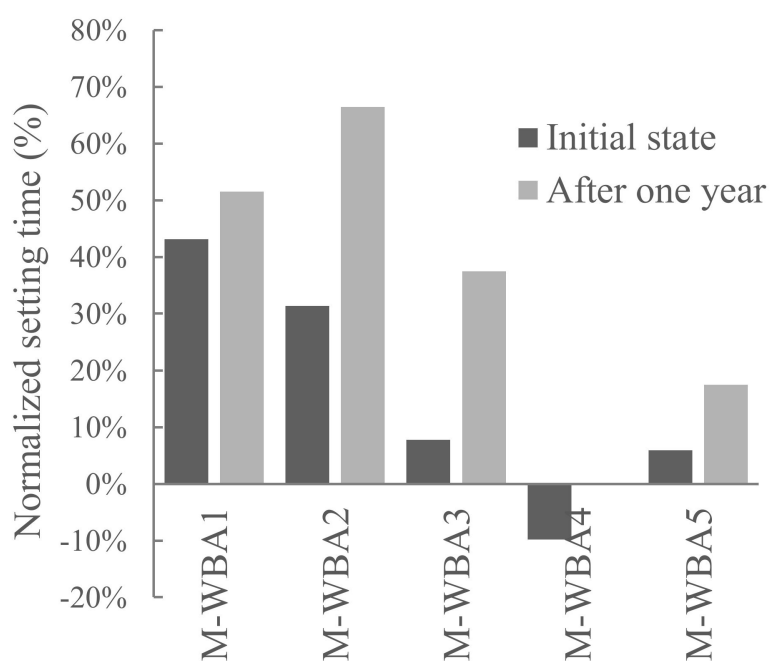

(d)

Figure 8. Properties of fresh paste as a function of the type and age of the WBA used as a 15\% cement replacement: (a) Standard consistency; (b) Paste temperature; (c) Initial setting time; (d) Final setting time (Values are normalized to the reference mix; the data are available in Supplementary Materials).

From Figure 8, it can be concluded that the water requirement increased at $15 \%$ cement replacement by WBA for both fresh and aged WBA. This is in agreement with $[57,58]$. In all samples prepared with aged WBA, the temperature of the paste was lower than samples prepared with fresh WBA. A possible explanation could be a decrease in free $\mathrm{CaO}$ (and periclase) after one year of storage, as shown in Figure 7. The free $\mathrm{CaO}$ (and periclase) hydration reaction releases heat, which can cause a temperature rise when fresh WBA is used. The initial setting time was increased for all cement paste samples, regardless of the age of the WBA used, except for sample WBA4. The same trend is seen in the pre-hydrated (aged) cement according to the research presented in [19]: The final 
setting time was prolonged while the initial setting time was decreased. The pre-hydrated cement showed unusual setting behaviour: Pre-hydrated cement shows an initial set before becoming plastic again and then subsequently hardening in a conventional manner, albeit much delayed [17]. As cement ages, hydration products form on the surface of its grains: products of calcium silicates and hydrates of calcium aluminate, portlandite and gypsum. The formation of gypsum disturbs the sulfate balance and delays the formation of ettringite and slows the setting time. This results in a quasi-flash set that disappears as the gypsum slowly goes into solution and reacts with the calcium aluminate hydrates [17]. Most likely, this trend is related to the WBA4 sample in terms of a different chemical composition in contrast to the other WBAs tested, which have lower $\mathrm{CaO}$ content and higher pozzolanic oxide content. For all the tested paste samples with aged WBA, the final setting time increased, i.e., the setting time is expected to increase with the aging of the WBA. The cement behaves in the same way with longer storage time.

Finally, it has been observed in previous studies that wood ash contributed to the evolution of heat during hydration [41]. Namely, with the addition of wood ash, more heat per $\mathrm{g}$ of cement was released during hydration. To evaluate whether aged WBA stored in closed container had the same effect on reactivity, the heat release was monitored on samples stored in closed containers for one year. Figure $9 a, b$ shows the influence of aged WBA after one year on the reaction rates of cement pastes using isothermal calorimetry.

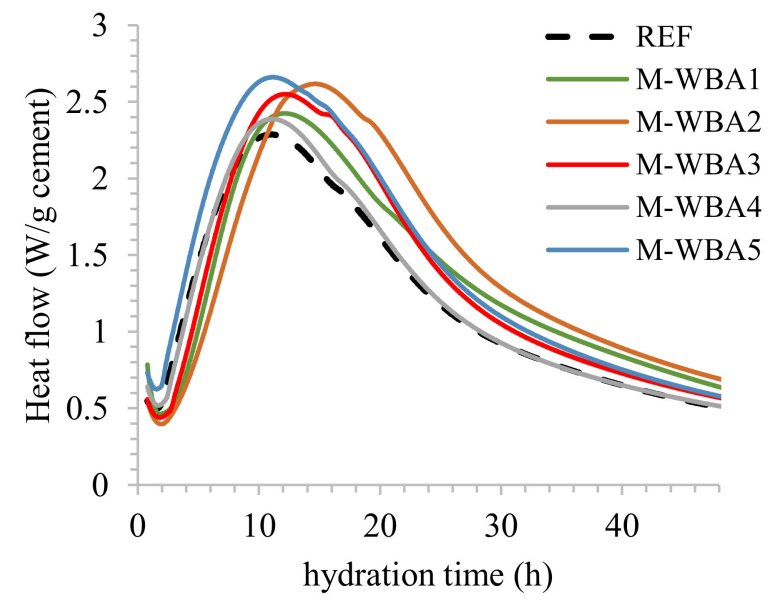

(a)

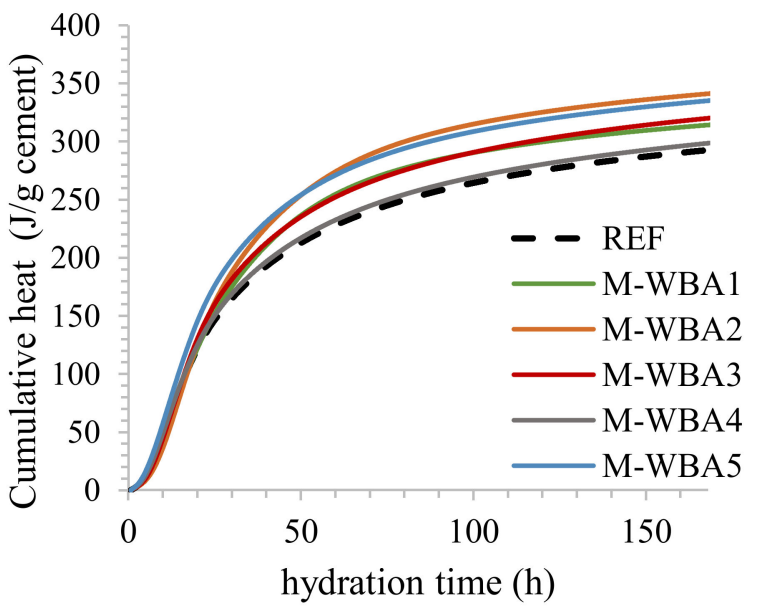

(b)

Figure 9. The influence of WBA after 1 year on the reactivity of pastes: (a) heat flow; (b) cumulative heat flow (the data are available in Supplementary Materials).

The increase in heat of hydration due to the use of pozzolans is usually attributed to the filler effect, i.e., particles smaller than cement fill spaces and allow higher nucleation and growth of hydration products and thus reactivity of cement [59]. However, since the WBA particles are larger here, compared to cement, the filler effect alone cannot be used to explain results obtained. Alternatively, hydration of free lime (and periclase) and $\mathrm{CaO}-$ (and $\mathrm{Al}_{2} \mathrm{O}_{3}$-) rich phases could be a possible explanation. In general, the addition of WBA increases and delays the heat flow, with the exception of the sample WBA5. This sample has the smallest particle size of all the WBA samples tested. For all other samples, the induction period is prolonged by the addition of WBA, which is consistent with [41]. This explains the prolonged setting times of all samples, except for the sample WBA5. The cumulative heat flow of the pastes with WBA is higher compared to the reference mix as follows: WBA2 $(2393.16 \mathrm{~J} / \mathrm{g})>\mathrm{WBA} 5(2353.35 \mathrm{~J} / \mathrm{g})>\mathrm{WBA} 3(2254.25 \mathrm{~J} / \mathrm{g})>\mathrm{WBA} 1$ $(2204.42 \mathrm{~J} / \mathrm{g})>$ WBA4 $(2106.65 \mathrm{~J} / \mathrm{g})$. According to studies on pre-hydration of cement [60], increased setting time, decreased compressive strength and heat of hydration, and altered 
rheological properties are expected. Here it is shown that there was no significant influence on the reactivity of the pastes during WBA aging.

The cumulative heat release of pastes with 15\% WBA as cement replacement was normalized to the cumulative heat release of the reference paste mixture and the influence of $\mathrm{PI}_{950}$ values and particle fineness is shown in Figures 10a and 10b, respectively.

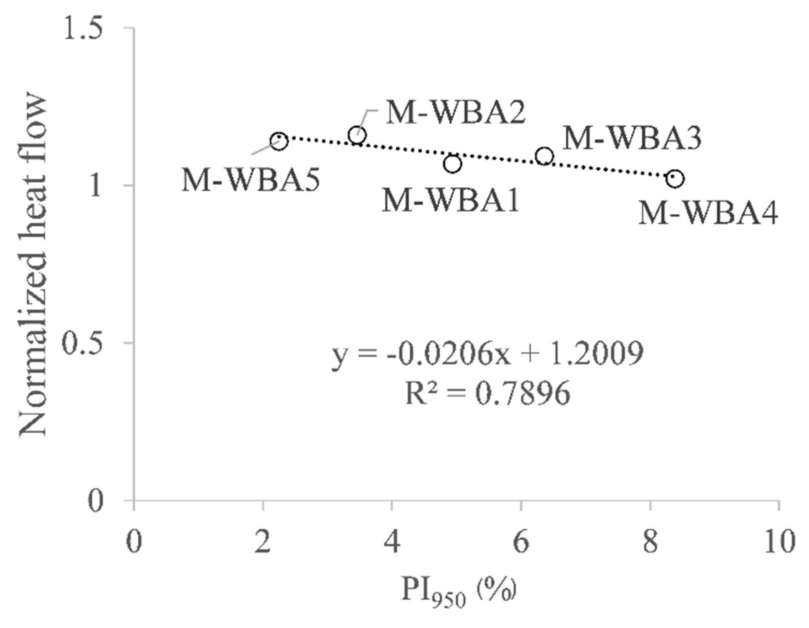

(a)

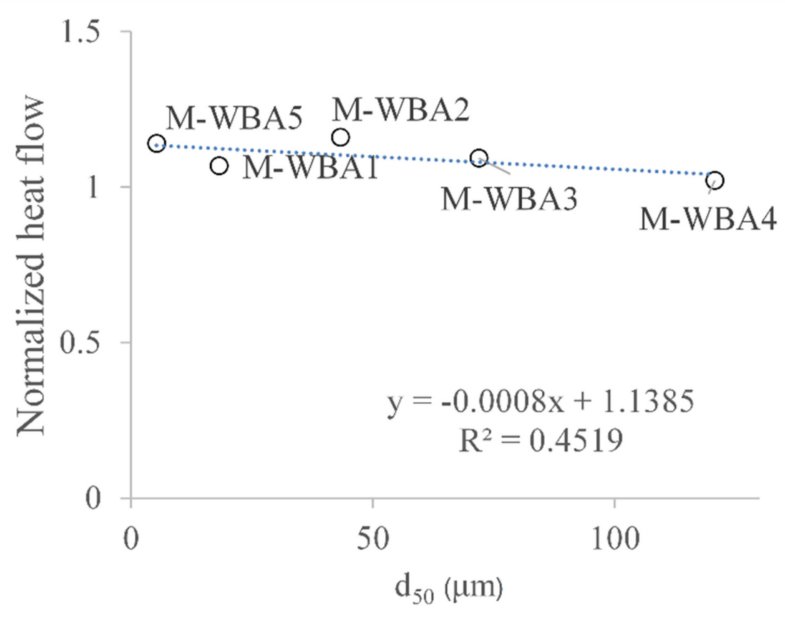

(b)

Figure 10. (a) Normalized cumulative heat flow after $168 \mathrm{~h}$ and $\mathrm{PI}_{950}$ values after one year of storage of WBA samples; (b) normalized cumulative heat flow after $168 \mathrm{~h}$ and $\mathrm{d}_{50}$ of WBA samples.

Figure 10a shows a reasonable linear relationship $\left(R^{2}=0.7896\right)$ between the prehydrated index of WBA samples and the normalized cumulative heat flow where with higher $\mathrm{PI}_{950}$ index the cumulative heat flow of the pastes decreases. Unfortunately, the influence of WBA itself during the collection was not analysed here (initial state). Therefore, the influence of WBA alone as a cement replacement and the influence of WBA aging on the reactivity of the pastes cannot be separated. Based on Figure 10b, it can be said that with smaller WBA particles, the cumulative heat flow is higher, but the linear dependence is not so convincing $\left(R^{2}=0.4519\right)$ compared to the previous linear relationship (between the PI index and the cumulative heat flow). Sample WBA4 has the highest influence on the reactivity of the pastes with WBA. Sample WBA4 has the highest PI value. Based on the TGA measurement (Figure 3), only WBA4 shows noticeable changes in the TG analysis after one year of sample aging, as indicated by a typical DTG peaks for the carbonated sample [61]. This WBA has the largest particles among all the WBAs tested, with half of the particles smaller than $120.7 \mu \mathrm{m}$. The WBA4 sample is richest in pozzolanic oxides, similar to coal fly ash [62], and one would expect an increase in heat hydration [63]. However, this is not the case here. Most likely, both parameters, the properties of the WBA and the aging of the samples used in pastes, had an influence on the reactivity and thus on the mechanical and durability properties when used in mortars and pastes.

\subsection{Aging of WBA Samples Stored in Opened Containers}

In the previous session, it was shown that the ageing of WBA behaves similarly to that of cement when stored in a closed environment. Since in the EU about $70 \%$ of WBA is disposed of in landfills [64] and in Croatia 61\% [35], it is necessary to analyse whether the storage of WBA in opened landfills (outside) has a stronger influence on WBA properties. In order to evaluate changes in mineralogical composition during outdoor storage in landfills, a TGA was performed. WBA samples were stored in open containers, which allowed reaction with moisture from the air. Using TG measurements of the WBA powders after 3 and 6 months of storage in open containers, the carbonate content determined according to Equation (1) was again compared to the initial state. The results indicate an increase 
in the carbonate phases from $18.6 \%$ (WBA4) to $52 \%$ (WBA5) for the samples stored in the open container. In order to distinguish the influence of carbonation and hydration of the WBA samples stored in open containers, different pre-hydration indices were calculated, Figure 11.

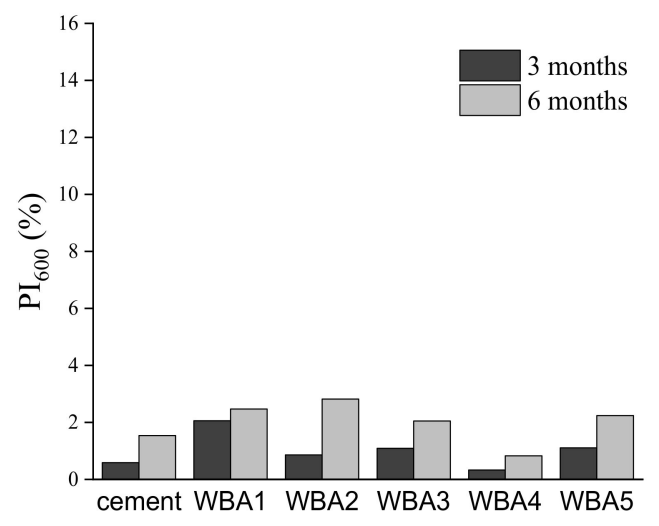

(a)

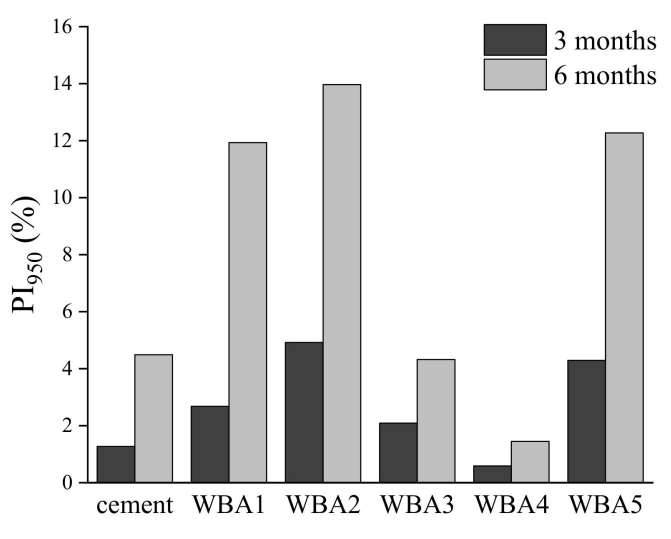

(b)

Figure 11. (a) $\mathrm{PI}_{600}$ value for WBA samples (aged for 3 and 6 months) for the temperature range between 35 and $600{ }^{\circ} \mathrm{C}$; (b) $\mathrm{PI}_{950}$ value for WBA samples (aged for 3 and 6 months) for the temperature range between 35 and $950{ }^{\circ} \mathrm{C}$.

Comparison between the two storage conditions clearly showed that WBA samples stored in air exhibited faster aging, i.e., a more significant increase in PI values in a shorter time (Figure 11) than those stored in closed containers (Figure 5). WBA stored in open containers showed an increase in PI values as follows: $\mathrm{PI}_{600}$ values increased from $0.83 \%$ (WBA4) to $2.82 \%$ (WBA2) after 3 months in air-open storage, while for $\mathrm{PI}_{950}$ they increased from 1.45 (WBA4) to $14 \%$ (WBA2). A significant increase in mass change due to hydration and carbonation is observed in the following order (from higher to lower values): WBA2 $(13.97 \%)>$ WBA5 $(12.27 \%)>$ WBA1 $(11.93 \%)>$ WBA3 $(4.31 \%)>$ WBA4 $(1.45 \%)$. In the case of open storage, a different reaction trend of the phases was noticed: Those WBA samples that had a higher proportion of free $\mathrm{CaO}$ reacted faster by reacting with water vapor from the air (ambient humidity) and hydration occurred. The high correlation of $\mathrm{PI}_{600}$ and $\mathrm{PI}_{950}$ with free $\mathrm{CaO}\left(\mathrm{R}^{2}=0.9519\right.$ and $\left.\mathrm{R}^{2}=0.7757\right)$ can be clearly seen in Figure 12 , indicating that in the case of open storage, carbonation is pronounced in samples with high values of free $\mathrm{CaO}$. This can be seen in the TGA diagrams through the second peak indicating the decomposition of portlandite (Figure 3).

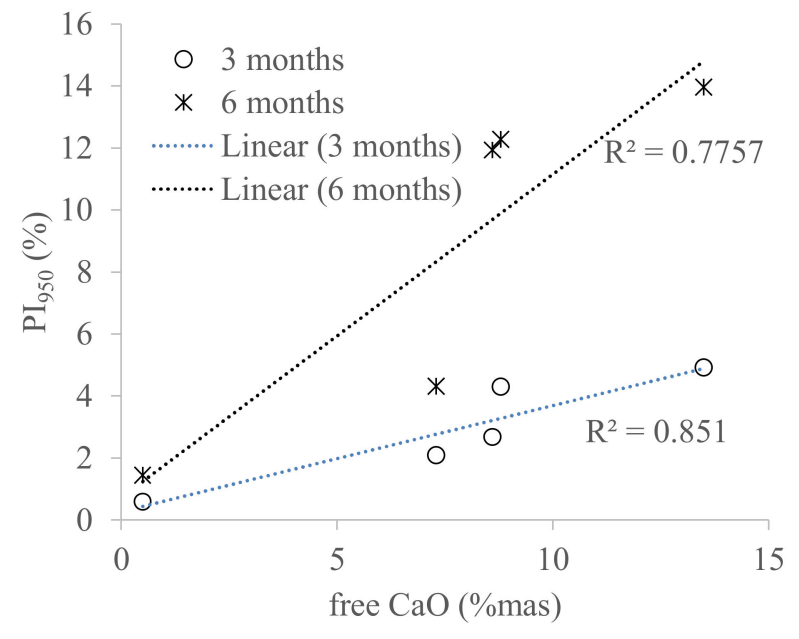

(a)

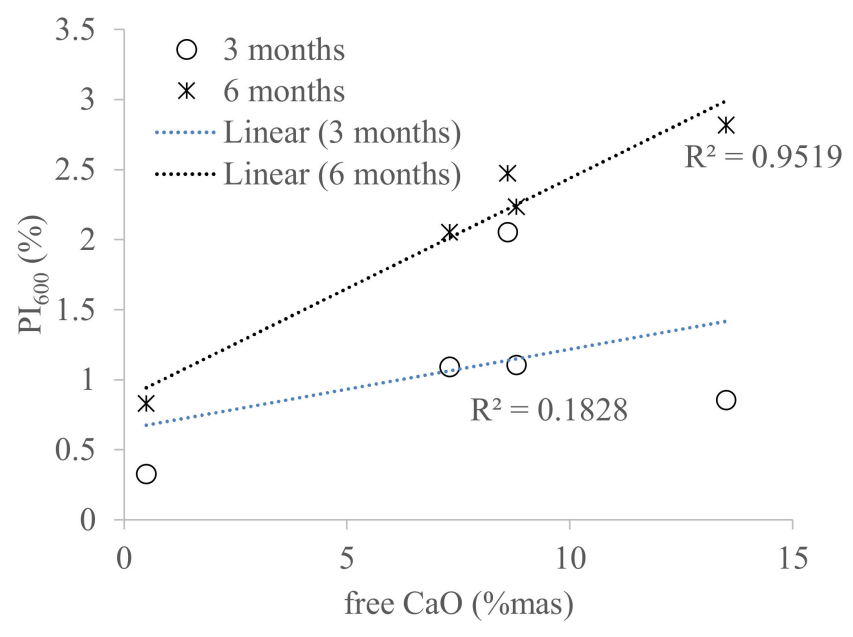

(b)

Figure 12. Effect of free $\mathrm{CaO}$ of WBA samples on prehydration index: (a) $\mathrm{PI}_{950}$ and (b) $\mathrm{PI}_{600}$. 


\section{Conclusions}

Wood biomass fly ashes from five different power plants were used in this study to evaluate the effect of WBA aging on the performance of cement composites. No significant change was observed in TG results after WBAs aging in closed containers for 28 days. However, after one year of storage of WBAs in closed containers, an increase in the amount of hydration and carbonation products is visible while the amount of free $\mathrm{CaO}$ was decreased. It was noticed that ageing has a greater impact in the case of WBA produced by grate combustion technology, but the possible influence of combustion technology on carbonation process of WBA samples should be further investigated. In general, samples with larger particle sizes exhibited faster carbonation. The results obtained indicate that when WBA is stored in closed containers, the free lime is stabilised over time, which is positive regarding risk of volume instability. The water requirement and the initial setting time were increased for all cement paste samples, regardless of the age of the WBA used, while the temperature of the paste was lower in the case when samples were made with aged WBA which can be attributed to a decrease in free lime (and periclase) after one year of storage. The final setting time increased for all paste samples tested with aged WBA. Nevertheless, the heat of hydration per $g$ of cement was still higher, indicating reactivity of the WBA even after one year of storage in the closed containers.

Under open storage conditions (simulating an open landfill), the predominant mechanism was hydration. Ashes with higher $\mathrm{CaO}$ content reacted more rapidly with moisture in the air. There was also significant carbonation, after only 3 months. It was expected that these phase changes of the material would also affect the properties of composites where WBA is used. Based on the result, it is not recommended to store reactive WBA in air, to avoid loss of its reactivity.

The comparison between the two storage conditions clearly showed that the WBA samples stored in air exhibited faster aging than those stored in closed containers. Based on the results obtained, it is recommended that WBA be collected and stored immediately in closed containers to prevent pre-hydration and carbonation.

This research should facilitate the assessment of applicability by end users (power plants as WBA producers and concrete producers as WBA users). The current research is valuable to power plants and concrete producers as it provides recommendations for the storage of WBA. Proper storage of WBA can ensure its use in cementitious composites and minimise the negative effects of improper storage on the beneficial cementitious properties of WBA.

Supplementary Materials: The following are available online at https:/ /www.mdpi.com/article/10 $.3390 / \mathrm{ma14071632/s1:} \mathrm{Excel} \mathrm{File.}$

Author Contributions: Conceptualization, I.C. and M.S.; methodology, I.C.; validation, I.C., M.S. and N.Š.; formal analysis, I.C.; investigation, I.C.; data curation, I.C., N.U. and M.S.; writing—original draft preparation, I.C., N.U. and M.S.; writing-review and editing, N.U. and N.Š.; visualization, I.C., M.S., N.U. and N.Š.; supervision, N.Š.; funding acquisition, N.Š. All authors have read and agreed to the published version of the manuscript.

Funding: This research was performed as a part of the research project IP-2016-06-7701 "Transformation of Wood Biomass Ash into Resilient Construction Composites", funded by the Croatian Science Foundation.

Institutional Review Board Statement: Not applicable.

Informed Consent Statement: Not applicable.

Data Availability Statement: The data presented in this study are available in Supplementary Materials.

Acknowledgments: This research was performed as a part of the research project IP-2016-06-7701 "Transformation of Wood Biomass Ash into Resilient Construction Composites", funded by the Croatian Science Foundation. The authors would like to thank Central Laboratory for Chemical Technology, a part of HEP Proizvodnja d.o.o. (Marija Trkmić) for assistance with TG measurements. 
Conflicts of Interest: The authors declare no conflict of interest.

\section{References}

1. Calderón, C.; Gauthier, G.; Jossart, J.-M. AEBIOM Statistical Report; European Bioenergy Outlook: Brussels, Belgium, 2016.

2. Eurostat Statistics Explained Renewable Energy Statistics. Available online: http://ec.europa.eu/eurostat/statistics-explained/ index.php/Renewable_energy_statistics (accessed on 1 July 2017).

3. European Statistics Energy from Renewable Sources. Available online: https://ec.europa.eu/eurostat/web/energy/data/shares (accessed on 15 May 2020).

4. Sikkema, R.; Proskurina, S.; Banja, M.; Vakkilainen, E. How can solid biomass contribute to the EU's renewable energy targets in 2020, 2030 and what are the GHG drivers and safeguards in energy- and forestry sectors? Renew. Energy 2021, 165, 758-772. [CrossRef]

5. Obernberger, I.; Supancic, K. Possibilities of Ash Utilisation from Biomass Combustion Plants. In Proceedings of the 17th European Biomass Conference \& Exhibition, Hamburg, Germany, 29 June-3 July 2009.

6. Doudart de la Grée, G.C.H.; Florea, M.V.A.; Keulen, A.; Brouwers, H.J.H. Contaminated biomass fly ashes-Characterization and treatment optimization for reuse as building materials. Waste Manag. 2016, 49, 96-109. [CrossRef]

7. Carević, I.; Serdar, M.; Štirmer, N.; Ukrainczyk, N. Preliminary screening of wood biomass ashes for partial resources replacements in cementitious materials. J. Clean. Prod. 2019, 229, 1045-1064. [CrossRef]

8. Sigvardsen, N.M.; Kirkelund, G.M.; Jensen, P.E.; Geiker, M.R.; Ottosen, L.M. Impact of production parameters on physiochemical characteristics of wood ash for possible utilisation in cement-based materials. Resour. Conserv. Recycl. 2019, 145, 230-240. [CrossRef]

9. Zagvozda, M.; Dimter, S.; Rukavina, T.; Grubeša, I.N. Possibilities of bioash application in road building. Građevinar 2018, 70, 393-402.

10. Ukrainczyk, N.; Koenders, E.A.B.; Stirmer, N. Transformation of Wood Ash Waste into Construction Materials. In Proceedings of the 1st International Conference on Construction Materials for Sustainable Future, Zadar, Croatia, 19-21 April 2017; pp. 101-108.

11. Omran, A.; Soliman, N.; Xie, A.; Davidenko, T.; Tagnit-hamou, A. Field trials with concrete incorporating biomass-fly ash. Constr. Build. Mater. 2018, 186, 660-669. [CrossRef]

12. Biedermann, F.; Obernberger, I. Ash-related Problems during Biomass Combustion and Possibilities for a Sustainable Ash Utilisation. In Proceedings of the International Conference “World Renewable Energy Congress" (WREC), Birmingham, UK, 28 February-2 March 2005; Elsevier BV: Oxford, UK, 2005; pp. 120-124.

13. Vassilev, S.V.; Baxter, D.; Andersen, L.K.; Vassileva, C.G. An overview of the composition and application of biomass ash.: Part 2 Potential utilisation, technological and ecological advantages and challenges. Fuel 2013, 105, 19-39. [CrossRef]

14. Jensen, O.M.; Hansen, P.F.; Lachowski, E.E.; Glasser, F.P. Clinker mineral hydration at reduced relative humidities. Cem. Concr. Res. 1999, 29, 1505-1512. [CrossRef]

15. Dubina, E.; Korat, L.; Black, L.; Strupi-šuput, J.; Plank, J. Spectrochimica Acta Part A: Molecular and Biomolecular Spectroscopy Influence of water vapour and carbon dioxide on free lime during storage at $80^{\circ} \mathrm{C}$, studied by Raman spectroscopy. Spectrochim. Acta Part A Mol. Biomol. Spectrosc. 2013, 111, 299-303. [CrossRef]

16. Getachew, B.; Adugna, T.; Assefa, S. Investigation on the effect of storage time dueto moisture absorption of cement on the properties of the concrete. Int. J. Dev. Res. 2018, 8, 18558-18561.

17. Whittaker, M.; Dubina, E.; Arkless, L.; Plank, J.; Black, L. The Effects of Prehydration on Cement Performance. In Proceedings of the 30th Cement and Concrete Science Conference, Birmingham, UK, 13-15 September 2010.

18. Ramge, P.; Schmidt, W. Effect of the storage of cement on early properties of cementitious systems. In Proceedings of the International Conference on Advances in Cement and Concrete Technology in Africa, Johannesburg, South Africa, 28-30 January 2013.

19. Whittaker, M.; Al-Mutawa, F.; Black, L.; Plank, J.; Dubina, E.; Arkless, L. The effect of prehydration on the engineering properties of CEM I Portland cement. Adv. Cem. Res. 2013, 25. [CrossRef]

20. Winnefeld, F. Influence of cement ageing and addition time on the performance of superplasticizers. ZKG Int. 2008, 61, 68-77.

21. Scrivener, K.; Snellings, R.; Lothenbach, B. A Practical Guide to Microstructural Analysis of Cementitious Materials, 1st ed.; CRC Press: Boca Ranton, FL, USA, 2017; ISBN 9781138747234.

22. Akinyemi, S.A.; Akinlua, A.; Gitari, W.M.; Khuse, N.; Eze, P.; Akinyeye, R.O.; Petrik, L.F. Natural weathering in dry disposed ash dump: Insight from chemical, mineralogical and geochemical analysis of fresh and unsaturated drilled cores. J. Environ. Manag. 2012, 102, 96-107. [CrossRef]

23. Gori, M.; Bergfeldt, B.; Pfrang-stotz, G.; Reichelt, J.; Sirini, P. Effect of short-term natural weathering on MSWI and wood waste bottom ash leaching behaviour. J. Hazard. Mater. 2011, 189, 435-443. [CrossRef] [PubMed]

24. Saffarzadeh, A.; Shimaoka, T.; Wei, Y.; Gardner, K.H.; Musselman, C.N. Impacts of natural weathering on the transformation / neoformation processes in landfilled MSWI bottom ash: A geoenvironmental perspective. Waste Manag. 2011, 31, 2440-2454 [CrossRef] [PubMed]

25. Meima, J.A.; Comans, R.N.J. The leaching of trace elements from municipal solid waste incinerator bottom ash at different stages of weathering. Appl. Geochem. 1999, 14, 159-171. [CrossRef] 
26. Polettini, A.; Pomi, R. The leaching behavior of incinerator bottom ash as affected by accelerated ageing. J. Hazard. Mater. 2004, 113, 209-215. [CrossRef]

27. Steenari, B.M.; Lindqvist, O. Stabilisation of biofuel ashes for recycling to forest soil. Biomass-Bioenergy 1997, 13, 39-50. [CrossRef]

28. Supancic, K.; Obernberger, I.; Kienzl, N.; Arich, A. Conversion and leaching characteristics of biomass ashes during outdoor storage-Results of laboratory tests. Biomass-Bioenergy 2014, 61, 211-226. [CrossRef]

29. Steenari, B.; Karlsson, L.G.; Lindqvist, O. Evaluation of the leaching characteristics of wood ash and the influence of ash agglomeration. Biomass-Bioenergy 1999, 16, 119-136. [CrossRef]

30. Karltun, E.; Saarsalmi, A.; Ingerslev, M.; Mandre, M.; Andersson, S.; Gaitnieks, T.; Ozolinčius, R.; Varnagiryte-Kabasinskiene, I. Wood Ash Recycling-Possibilities and Risks. In Sustainable Use of Forest Biomass for Energy; Managing Forest Ecosystems; Springer: Dordrecht, The Netherlands, 2008; pp. 79-108. [CrossRef]

31. Ukrainczyk, N. Reuse of Woody Biomass Ash Waste in Cementitious Materials. Chem. Biochem. Eng. Q. 2016, 30, 137-148. [CrossRef]

32. Ohenoja, K.; Tanskanen, P.; Wigren, V.; Kinnunen, P.; Körkkö, M.; Peltosaari, O.; Österbacka, J.; Illikainen, M. Self-hardening of fly ashes from a bubbling fluidized bed combustion of peat, forest industry residuals, and wastes. Fuel 2016, 165, 440-446. [CrossRef]

33. Tishmack, J.K.; Olek, J.; Diamond, S. Characterization of High-Calcium Fly Ashes and Their Potential Influence on Ettringite Formation in Cementitious Systems. Cem. Concr. Aggregates 1999, 21, 82-92. [CrossRef]

34. Holmberg, S.L.; Claesson, T. Mineralogy of granulated wood ash from a heating plant in Kalmar, Sweden. Environ. Earth Sci. 2001, 40, 820-828. [CrossRef]

35. Milovanović, B.; Štirmer, N.; Carević, I.; Baričević, A. Wood biomass ash as a raw material in concrete industry. J. Croat. Assoc. Civ. 2019, 71, 505-514. [CrossRef]

36. Carević, I.; Baričević, A.; Štirmer, N.; Bajto Šantek, J. Correlation between physical and chemical properties of wood biomass ash and cement composites performances. Constr. Build. Mater. 2020, 256, 119450. [CrossRef]

37. Stoian, J.; Oey, T.; Bullard, J.W.; Huang, J.; Kumar, A.; Balonis, M.; Neithalath, N.; Sant, G. The Prehydration of Cement and Its Mitigation. In Proceedings of the 2nd International Congress on Durability of Concrete, New Delhi, India, 4-6 December 2014.

38. Chung, F.H. Quantitative interpretation of X-ray diffraction patterns of mixtures. I. Matrix-flushing method for quantitative multicomponent analysis. J. Appl. Crystallogr. 1974, 7, 519-525. [CrossRef]

39. The European Committee for Standardization. Methods of Testing Cement_Part 3: Determination of Setting Times and Soundness (EN 196-3:2016); The European Committee for Standardization (CEN): Brussels, Belgium, 2016.

40. Medina, J.M.; Sáez del Bosque, I.F.; Frías, M.; Sánchez de Rojas, M.I.; Medina, C. Durability of new blended cements additioned with recycled biomass bottom ASH from electric power plants. Constr. Build. Mater. 2019, 225, 429-440. [CrossRef]

41. Ukrainczyk, N.; Ukrainczyk, M.; Sipusic, J. XRD and TGA investigation of hardened cement paste. In Proceedings of the MATRIB 2006 International Conference on Materials, Tribology, Recycling, Vela Luka, Croatia, 22-24 June 2006.

42. Deboucha, W.; Leklou, N.; Khelidj, A.; Oudjit, M.N. Hydration development of mineral additives blended cement using thermogravimetric analysis (TGA): Methodology of calculating the degree of hydration. Constr. Build. Mater. 2017, 146, 687-701. [CrossRef]

43. Misra, M.K.; Ragland, K.W.; Bakert, A.J. Wood ash compostion as a function of furnace temperature. Biomass-Bioenergy 1993, 4, 103-116. [CrossRef]

44. Straka, P.; Náhunková, J.; Margit, Z. Analysis of unburned carbon in industrial ashes from biomass combustion by thermogravimetric method using Boudouard reaction. Thermochim. Acta 2014, 575, 188-194. [CrossRef]

45. Mohebbi, M.; Rajabipour, F.; Scheetz, B.E. Evaluation of two-atmosphere thermogravimetric analysis for determining the unburned carbon content in fly ash. Adv. Civ. Eng. Mater. 2017, 6, 258-279. [CrossRef]

46. Bernal, S.A.; Juenger, M.C.G.; Ke, X.; Matthes, W.; Lothenbach, B.; Belie, N. De Provis, J.L. Characterization of supplementary cementitious materials by thermal analysis. Mater. Struct. 2017, 50, 1-13. [CrossRef]

47. The European Committee for Standardization. Fly Ash for Concrete-Part 1: Definition, Specifications and Conformity Criteria; British Standards Institution: Lodon, UK, 2012.

48. Sigvardsen, N.M.; Geiker, M.R.; Ottosen, L.M. Phase development and mechanical response of low-level cement replacements with wood ash and washed wood ash. Constr. Build. Mater. 2020, 269, 121234. [CrossRef]

49. Chatterji, S. Mechanism of expansion of concrete due to the presence of dead-burnt CaO and MgO. Cem. Concr. Res. 1995, 25, 51-56. [CrossRef]

50. Arjunan, P.; Kumar, A. Rapid techniques for determination of free lime and free magnesia in cement clinker and portlandite in hydrates. Cem. Concr. Res. 1994, 24, 343-352. [CrossRef]

51. Pielert, J.; Lamond, J.H. (Eds.) Significance of Tests and Properties of Concrete and Concrete-Making Materials, STP 169D. Lamond; ASTM International: Conshohocken, PA, USA, 2006.

52. Lagerlund, J. Long Term Effects on Stored Calcium Rich Fly Ash as Relevant to Cement Replacement. In Proceedings of the Ash Utilisation 2012, Ashes in a Sustainable Society, Stockholm, Sweden, 25-27 January 2012.

53. Janz, M.; Jihansson, S.-E. The Function of Different Binding Agents in Deep Stabilization; Swedish Deep Stabilization Research Centre: Linköping, Sweden, 2002; pp. 1-50.

54. Tepsri, P.; Chumphu, A.; Yoriya, S. High-calcium fly ash recovery from wet-stored condition and its properties High-calcium fl y ash recovery from wet-stored condition and its properties. Mater. Res. Express 2018, 5, 115506. [CrossRef] 
55. Korat, L. Characterization of the Cement Composities with Mineral Additives (in Slovenian). Ph.D. Thesis, Faculty of Natural Science and Engineering University of Ljubljana, Ljubljana, Slovenia, 2015.

56. Yeheyis, M.B.; Shang, J.Q.; Yanful, E.K. Chemical and Mineralogical Transformations of Coal Fly Ash after Landfilling. In Proceedings of the 2009 World of Coal Ash (WOCA) Conference, Lexington, KY, USA, 4-7 May 2009; pp. 1-13.

57. Berra, M.; Mangialardi, T.; Paolini, A.E. Reuse of woody biomass fly ash in cement-based materials. Constr. Build. Mater. 2015, 76, 286-296. [CrossRef]

58. Rajamma, R.; Senff, L.; Ribeiro, M.J.; Labrincha, J.A.; Ball, R.J.; Allen, G.C.; Ferreira, V.M. Biomass fly ash effect on fresh and hardened state properties of cement based materials. Compos. Part B Eng. 2015, 77, 1-9. [CrossRef]

59. Skibsted, J.; Snellings, R. Reactivity of supplementary cementitious materials (SCMs) in cement blends. Cem. Concr. Res. 2019, 124, 1190-1199. [CrossRef]

60. Dubina, E. The Phenomenon of Cement Ageing on Moist Air: Surface Chemistry, Mechanisms and Effects on Admixture Performance. Ph.D. Thesis, Technical University of Munich, Munich, Germany, 2013.

61. Villain, G.; Thiery, M.; Platret, G. Measurement methods of carbonation profiles in concrete: Thermogravimetry, chemical analysis and gammadensimetry. Cem. Concr. Res. 2007, 37, 1182-1192. [CrossRef]

62. Shafigh, P.; Hashemi, M.; Nam, B.H.; Asadi, I.; Lumpur, K.; Shafigh, P.; Hashemi, M.; Nam, B.H.; Asadi, I.; Hashemi, M.; et al. Laboratory comparison of roller-compacted concrete and ordinary vibrated concrete for pavement structures. Građevinar 2020, 72, 127-137.

63. De Weerdt, K.; Ben Haha, M.; Le Saout, G.; Kjellsen, K.O.; Justnes, H.; Lothenbach, B. Hydration mechanisms of ternary Portland cements containing limestone powder and fly ash. Cem. Concr. Res. 2011, 41, 279-291. [CrossRef]

64. Chowdhury, S.; Mishra, M.; Suganya, O. The incorporation of wood waste ash as a partial cement replacement material for making structural grade concrete: An overview. Ain Shams Eng. J. 2015, 6, 429-437. [CrossRef] 